\title{
International Society of Leather Trades' Chemists
}

\section{Conference at Copenhagen}

$\mathrm{T}$

HE biennial conference of the International Society of Leather Trades' Chemists took place at Copenhagen on August 29-September 2, the meetings being held in the Technological Institute there. The president for the years $1938-39$ is $\mathrm{Mr}$. W. R. Atkin (England). It was announced that the Procter Memorial Research Fellowship Fund had reached a total of $£ 3,400$, and it was hoped to appoint the first research scholar in October 1938. It was also decided to institute a Procter Memorial Lecture to be delivered at all future conferences, and the first will be delivered in London in 1939. Dr. E. Schell (France) was made an honorary member of the Society.

Several combined sessions were held with the German Internationalen Vereins der Leder Industrie Chemiker, before which many interesting communications were made.

Dr. K. Linderström-Lang gave the opening lecture on the constitution of proteins as elucidated by enzyme studies. Dr. Dorothy Jordan Lloyd followed with a paper on the swelling of structured proteins with special reference to the influence of the reticular tissue on the swelling of collagen in alkaline solutions.

Mr. W. R. Atkin discussed the titration curves of gelatin and collagen, pointing out that, by the application of the Procter-Wilson theory to the titration curve of gelatin, it was possible to construct a replica of the swelling curve of gelatin in hydrochloric acid. It was also demonstrated that the second isoelectric point of gelatin postulated by Wilson could not exist. Dr. F. Schneider gave a paper on the hide proteins, emphasizing that various hide proteins could be distinguished by determining their sugar and amino. acid contents. Dr. F. Stather dealt with the technical problems of fat-liquoring and stuffing of leathers, while several aspects of the chemical testing of vegetable tanned leather were dealt with by Dr. V. Kubelka.

Mr. G. Parsy discussed the $p H$ values of sulphonated oils, and a new electrode for $p H$ determinations was demonstrated by J. Haugaard. Dr. D. Burton described a method for determining the amount of neutralizing agent required by a chrome leather, and Dr. K. H. Gustavson discussed the concept of the chrome-collagen compound as an internal complex salt. The tanning effect of polytungstic acid was described by Dr. C. Riess, and Dr. E. Elod pointed out in his paper the use of polyvinyl alcohol as a substitute for proteins in tanning research experiments. Dr. G. Otto compared the titration curves of synthetic tannins with those of natural tannins, and Dr. W. Grassmann described a nephelometric micro-method for the identification and estimation of tannins.

Mr. A. Dohogne discussed the relative water permeabilities of sole leathers tanned by slow and rapid methods, and Dr. A. Miekerley described some work on the combination of lignin sulphonic acids with hide substance. The fractional extraction of pine bark was the subject of a paper by Dr. Vl. Nemec, while Dr. L. Pollak explained methods for the chemical control of hide soak liquors.

During the official banquet which followed the conference, Dr. E. Stiasny was presented with the first copy of a special "Festschrift" volume published to commemorate his sixty-fifth birthday, to which contributions have been made by well-known leather chemists throughout the world.

\section{Metallurgy and the Aero Engine}

$\mathrm{T}$ HE sixteenth Autumn Lecture of the Institute of Metals was delivered by Dr. D. R. Pye, director of scientific research to the Air Ministry, on "Metallurgy and the Aero Engine", at the Sheffield meeting on September 6 .

During recent years, there has been a remarkable increase in the power output from aero engines. A comparison of two engines of the same general type and cylinder capacity shows an increase in the last seven years of more than a hundred per cent. This increase has been achieved by improvements in the quality of the fuel, which allows the combustible mixture to be supplied by a supercharger at a higher pressure and temperature. A parallel improvement in the materials of construction to meet the severe conditions of temperature and mechanical loading has taken place, and there is scarcely one major component of the two engines of which either the material or its treatment has not been modified. The problems so far as they concern the metallurgist are both thermal and mechanical. It is fundamentally impossible greatly to increase the proportion of the heat generated which is turned into mechanical work.
The marked increase of power has, therefore, involved a corresponding increase in the waste heat which is to be removed. The piston, which must be receiving about forty per cent more heat, is a critical factor and the temperature attained on the piston is, from examination of the recrystallization of aluminium alloy pistons after use, of the order of $450^{\circ} \mathrm{C}$.

The discovery of a now material of about the same specific gravity and thermal conductivity, but better able to maintain its strength at temperatures of $300^{\circ} \mathrm{C}$. and above, would be one of major importance.

The increase of waste heat, combined with the chemical problems introduced by the use of lead tetra-ethyl in the fuel, has profoundly affected the metallurgy of the exhaust valve. In spite of great improvements in the steel, it is now necessary not only to transfer heat away from the valve head by means of hollow valves containing liquid, but also to coat the valve with special alloys to resist oxidation at the high temperatures involved. Improvements of sparking plugs involve interesting problems in which the engineer needs the help of the physicist. 
On the mechanical side, the chief metallurgical problem of the aero engine is that of maintaining two surfaces rubbing together at high temperatures without seizure. This is essentially a problem of lubrication, but as the temperatures of the working surfaces increase, the viscosity of the oil gives less and less protection, and the nature of the metal surfaces themselves will play a more important part.

Working surfaces are never flat when considered in terms of molecular dimensions, and it becomes, therefore, of great importance to examine the possibility of the treatment of the surfaces in such a way as to render them less liable to seizure. The line taken by the engineer at present is to use one of the recognized methods of producing a hardened surface, but much further knowledge in this direction is still required. Beilby showed thirty-five years ago that during the polishing process the normal structure of metal is destroyed and the surface becomes amorphous. This conclusion has been confirmed by the recent work of Finch and Bowden. It has been shown that during the 'running-in' process a very thick Beilby layer of amorphous material is produced on the surface of a steel cylinder. Apart from the fact that observations have shown that a metal in. the amorphous condition is harder and tougher than the crystalline variety, it is, in Dr. Pye's opinion, reasonable to suppose that an amorphous surface could be more easily protected from seizure by a thin oil film than could one of a crystalline character.

Such problems can only be successfully surmounted by the engineer with the advice of the physicist, and they are bound to assume a steadily greater importance where rubbing surfaces have to survive without seizure under high temperature conditions.

\section{Science News a Century Ago}

\section{Faraday and Schönbein}

ON September 21, 1837, Faraday wrote to Schönbein, from the Royal Institution, "Your very pleasant and acceptable letter of the 9th of July with the accompanying books I received only last week, while at Liverpool, at the very meeting you refer to and $I$ heartily wish that you had been there yourself. It is now five years since I have been able to attend any of these meetings but I was very pleased with the one to which I now refer. . . . As the Association forms no collection of books or apparatus I gave the said copy of your work to Professor Henry of Phila. delphia in the United States with a view of extending what you have done as far and as fast as possible and wherever the English language is found. He was exceedingly obliged to me for it and I only wish that you and he had met at Liverpool. . . .

"With regard to Mr. Crosse's insects, etc., I do not think anybody believes in them here except perhaps himself and the mass of wonder-lovers.-I was said in the English papers to have proved the truth of his statement, but I immediately contradicted the matter publicly. . . . It is but just of me to say that in conversation with $\mathrm{Mr}$. Crosse I was very much pleased with him and with the readiness with which he received my critical remarks. As regards the cristallization supposed as real, he was lugged into view and must not be charged with having pressed himself forward. He is in fact a very modest man but has been dragged into an unkind situation. . . ."

\section{David Uwins (1780-1837)}

Dr. David Uwins, one of the first English converts to homœopathy, was born in London in 1780 , the son of Thomas Uwins, a clerk in the Bank of England and brother of Thomas Uwins, the artist. He received his medical training in London and then went to Edinburgh, where he graduated M.D. in 1803. He then returned to London, where he was made L.R.C.P. in 1807 . In 1815 he was appointed physician to the City Dispensary and afterwards to the Finsbury and Central Dispensary. In 1828 he became physician to the lunatic asylum at Peckham, and as the result of his experience in that institution published in 1833 "A Treatise on those Disorders of the Brain and Nervous System called Mental". In later life, owing to the influence of his friend Frederick Hervey Quin, he took up homoopathy, and in 1836 announced his conversion to that doctrine in a pamphlet entitled "Homœopathy and Allopathy, or Large, Small and Atomic Doses". As the result of this step he quarrelled with his former friends and his health broke down owing to the stress of controversy. He died in London on September 22, 1837, and was buried in Kensal Green Cemetery.

Uwins was a prolific writer. In addition to the works already mentioned his chief publications were "Modern Medicine, containing a Brief Exposition of the Principal Discoveries and Doctrines" (1808), "A Compendium of Theoretical and Practical Medicine" (1825) and "A Treatise on those Diseases which are either directly or indirectly connected with Indigestion, and on the Principal Ailments of Children" (1827). He also contributed medical articles to Gregory's "Encyclopædia" and the Quarterly Review, and was for some time editor of the Medical Repository.

\section{Lyell to Leonard Horner}

Lyell had spent the months June to September 1837 on the Continent and thus had not been able to attend the British Association meeting at Liverpool. Just before he returned home he wrote on September 23 from Paris to Leonard Horner (17851864), the geologist, "I am glad to receive your report of the meeting at Liverpool, and to hear the Association was so well supported. I must try to be at the next. I saw a very blundering account of my letter in the 'Athenæum'. I am anxious that when printed by the Association, it should be given as I sent it, and this principally because I have carefully avoided bringing prominently forward any collision with Von Buch, whom I like too well not to be sorry that he should fancy, as he has done before now, that I am always seeking to run against him. I only mentioned him as having been the first to announce the posteriority of the granite to the transition beds, which was a grand step at that time, and true; though perhaps he did not come at it by a strictly logical course. I knew how he drew his inferences, which were quite natural twenty-six years ago, before he had adopted the true theory of granite, but had I brought forward his errors, I should also have dwelt on his praises. Chancellor Brougham said of Serjeant Wilde, that it was rather hard to visit on the barrister the sins which he committed in the flesh as an attorney, and I should also think it hard to show up the mistakes which Von Buch the Huttonian fell into, in the youthful days of his Wernerianism." 